\title{
TOPICAL EFFECT OF MINOXIDIL CONTAINING LOTION ON MORPHOFUNCTIONAL INDICATORS OF MALE RATS' REPRODUCTIVE SYSTEM
}

\author{
V. Turkina, N. Chemodurova, O. Hrushka, H. Pryzyhlei \\ Danylo Halytsky Lviv National Medical University, Lviv, Ukraine
}

\begin{abstract}
The problem of alopecia, for treatment of which the use of over the counter lotions containing minoxidil is recommended, is paid considerable attention all over the world. The consumers rarely seek medical advice due to certain psychological barriers. Thus, it contributes to the uncontrolled use of the drugs, and fixation of their side effects becomes impossible. There are isolated reports on the effect of minoxidil containing lotions on male fertility.

The Aim. To establish organometric parameters of testes and their paradidymis, functional parameters of spermatozoa in mature rats under topical exposure to a $10 \%$ minoxidil containing lotion.

Methods. Analytical, toxicological, statistical.

Results. It was established that under the conditions of 72-day percutaneous application of $10 \%$ minoxidil containing lotion some changes in the reproductive system organs can be observed, which are in particular a decrease in the mass of testes and epididymis, as well as a decrease in organs' linear size. The total time of motor activity of gametes after exposure to a lotion containing $10 \%$ minoxidil has statistically significantly shortened, a 6-fold inhibition of the activity of redox processes occurred in the rats of the experimental group compared to the control one.

Conclusions. Taking into consideration the obtained data and the uncontrolled and long-term use of $10 \%$ minoxidil containing lotions by men of reproductive age, an in-depth study of its gonadotoxic effects in experimental conditions in combination with epidemiological studies of the patients using these lotions is deemed necessary.
\end{abstract}

Key Words: minoxidil, gonadotoxicity, mature rats.

Introduction. Scientific papers of the last decade describe a noticeable decrease in spermatogenic function in men from different regions of the world [1, 2]. Among the etiological factors that are the cause of this situation an important role is played by pharmaceuticals. A significant number of drugs have been studied to determine their effect on spermatogenesis and spermatozoa parameters. It is noted that the effect of pharmaceutical substances (except for cytotoxic drugs) is usually reversible upon termination of treatment. The list of drugs with possible gonadotoxic activity includes antihypertensive vasodilator minoxidil [3]. The mechanism of its adverse effect on male fertility is probably related to the generally recognized ability of calcium channel blockers to reduce spermatozoa viability and motility as a result of modified transmembrane calcium movement, as described in vitro experiments [4].

At the moment, in modern trichology minoxidil containing lotions are recommended as the most effective means of combating androgenic alopecia $[5,6]$. They belong to the over-the-counter group of drugs and are often positioned by manufacturers as "medical cosmetics". Becausemost men with various forms of alopecia feel a certain psychological barrier, they do not seek medical help, but seek solutions to their problem outside medical facilities. Furthermore, for those suffering from alopecia, to significantly improve hair growth a long-term use of lotions of at least 4-6 months, is recommended, and to maintain the effect, it is recommended to continue using them indefinitely $[7,8,9]$. This situation contributes to the uncontrolled use of lotions containing minoxidil; therefore, trichologists cannot control the regimes and doses and record possible side effects. The presented data is the basis for the understanding of safety of minoxidil containing lotions for male reproductive system.

It should be noted thatandrogens are the main hormonal regulators of hair growth [10]. According to Sato et al. [11] minoxidil in human dermal cell culture is able to increase the activity of enzymes involved in androgen metabolism. Later it was found that skin cells are able to synthesize androgens from the precursors of the gonads or adrenal glands, and enzymes involved in skin steroidogenesis are involved in normal or pathological processes [12]. Therefore, the use of minoxidil containing lotions can lead to disruption of biochemical regulatory processes that are associated 
with hormonal balance in the body. Confirmation of this assumption can be found inpublications of recent years, where a negative effect of minoxidil on male reproductive system is described [13].

The Aim of the Research. To study the organometric parameters of the testes, their paradidymis and the functional parameters of spermatozoa in mature ratsunder the topical effect of a $10 \%$ minoxidil containing lotion.

Methods and Materials. The experimental work was performed on 20 white outbred male rats. The animals were on a standard diet and drinking ration. All rats were in an active mature state.

The experimental work with animals was performed in accordance with the national "General ethical principles for experiments on animals", which are consistent with the provisions of the "European Convention for the Protection of Vertebrate Animals Used for Experimental and Other Scientific Purposes" [14].

Rats were divided into two groups - the control and the experimental one, ten animals in each. A solvent - ethyl alcohol was applied on control animals, $10 \%$ minoxidil containing lotion - on experimental animals. In 71 days from the start of the experiment, rats were weighed and removed from the experiment by decapitation under ether anaesthesia. The choice of the time framework of the experiment was determined by the need to complete at least one cycle of spermatogenesis. The full cycle of development of spermatozoa in rats is 48 days; the passage through the canals of the epididymis lasts for about 4 weeks[15].

The internal organs of the reproductive system were removed as a single organ complex and carefully prepared [16]. An external examination of the gonads was performed to detect circulatory disorders, inflammatory changes, dystrophy (atrophy) and abnormalities. Thetestes and their epididymis were then weighed,and theirlinear dimensions (length, width) were included as the biometric parameters of the testes. The relative weight of testes and epididymis in relation to body weight (in \%) was calculated.

In order to study the functional state of spermatozoa a suspension obtained by longitudinal section of the epididymis, followed by their extraction for 2 minutes in $10 \mathrm{ml}$ of saline heated to $37^{\circ} \mathrm{C}$, was used.
To determine the total number of spermatozoa, a suspension of epididymis in saline, a WBC count pipette and Goryaev chamber were used.

The number of abnormal spermatozoa was counted under a light microscope with a magnification power of $\times 400$. A spermatozoon was considered morphologically abnormal if at least one of its parts (head, middle part or tail) had structural abnormalities visible under a light microscope.

The functional state of spermatozoa was examinedaccordingto the following parameters: duration of motility, determination of the relative number of live spermatozoa, their viability in chemical solutions that meet physiological conditions (acid and osmotic resistance) and respiratory rate (redox processes) in the test with methylene blue [17].

Analysis and processing of the study results was performed using a computer system Microsoft Excel 7.0. The normality of the distribution was checked using the Shapiro-Wilk test. The significance of the differences of the mean values for the samples with parametric distribution was evaluated using the Student's $t$ test. When comparing indicators, the distribution of which did not comply with the law of normality, the Mann-Whitney U test was used in two independent groups. Parametric data are described by mean value (M) and standard deviations (SD); nonparametric - using the median (Me) and quartiles. The critical level of significance in testing statistical hypotheses was taken as $\mathrm{p} \leq 0.05$ [18].

Results and Discussion. Percutaneous application of the $10 \%$ minoxidil containing lotion did not cause intoxication and mortality in experimental animals throughout the experiment; the phenomena of skin irritation were not detected.The weight of the experimental rats was $266 \pm 20.25 \mathrm{~g}$ and had no significant differences compared to the controlones.

A significant decrease in organometric parameters of the testes and epididymis was observed in animals of the experimental group (Fig.). The average of $12 \%(\mathrm{p}<0.05)$ decrease in testicular weight and mass coefficients compared to animals of the control group and reference values occurred [19]. The mass of seminal epididymis in animals of the experimental group decreased by $13.29 \%(\mathrm{p}<0.05)$, their mass coefficients decreased by $12.08 \%(p<0.05)$ compared to the control group. The sizesofthe 


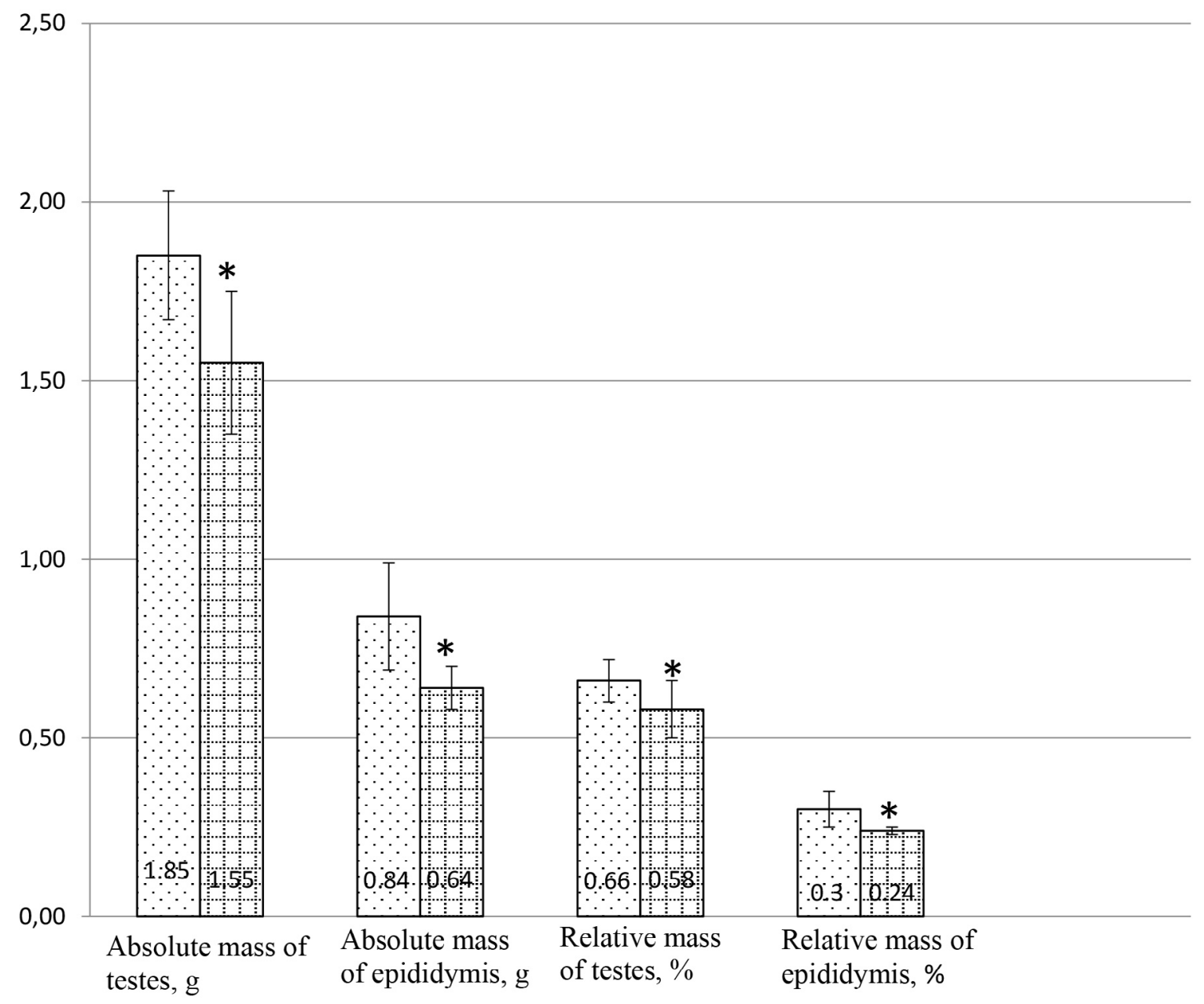

Fig. Macrometric parameters of white rats under the influence of $10 \%$ minoxidil containing lotion Note * - the differences are statistically significant compared to the control at $<0.05$

testes in animals of experimental group were also $12 \%$ lower than that of the animals in the control group.

Thus, it was found that under the conditions of 72-day percutaneous application of $10 \%$ minoxidil containing lotion there are certain changes in the organs of the reproductive system, which are manifested by a decrease in the mass of testes and epididymis, as well as a change in organs' linear size. These changes indicate a decrease in the secretory function of these organs.

The results of the study of the epididymal suspension showed that the $10 \%$ minoxidil lotion under these experimental conditions does not cause statistically significant changes in the production of gametes. Microscopic examination of spermatozoa morphological features revealed, along with normal cells, single pathological forms, which occurred with the same frequency in rats of the experimental and control groups (Table 1).
Indicators that indirectly demonstrate the energy capabilities of spermatozoa (the nature of motion activity, duration of movement) and their resistance to changes in the environment osmotic and acid resistancewere studied (Table 2).

Spermatozoa viability has not changed significantly. At the same time, the total time of motion activity of gametes after exposure to $10 \%$ containing minoxidil lotion has statistically significantly shortened in research groups. Activation of spermatozoa motility is a calcium-dependent process, which requires a balance of the calcium content of the extracellular space and internal depots [20]. As mentioned above [4], minoxidil is actively involved in the functioning of ion pumps and channels. Thus, interference in the transmembrane transportation of calcium may be the basis for the mechanism of its negative impact on the motility of gametes. 
Qualitative indicators of epididymal spermatozoa of male rats

\begin{tabular}{|c|c|c|}
\hline Indicators of epididymal spermatozoa & Control group & Experimental group \\
\hline Total number, $\mathrm{m}$. & $96[80 ; 103]$ & $97[84 ; 99]$ \\
\hline Pathological forms, $\%$ & $0.31[0.20 ; 0.58]$ & $0.3[0.2 ; 0.54]$ \\
\hline The number of dead spermatozoa, $\%$ & $0.25[0.0 ; 0.88]$ & $0.0[0.0 ; 0.0]$ \\
\hline
\end{tabular}

Functional indicators of spermatogenesis of white rats under the

Table 2 in fluence of $10 \%$ minoxidil containing lotion

\begin{tabular}{|c|c|c|}
\hline Indicators & Indicators & Experimental group \\
\hline 1 & 2 & 3 \\
\hline Acid resistance, $\mathrm{pH}$ & $2.5[2.13 ; 2.5]$ & $2.4[2.0 ; 2.5]$ \\
\hline Osmotic resistance, $\% \mathrm{NaCl}$ solution & $2.42 \pm 0.3$ & $2.48 \pm 0.21$ \\
\hline Redox reactions, min & $65.0[40.8 ; 73.8]$ & $407.0[266.5 ; 460.5]^{*}$ \\
\hline Spermatozoa motility, min & $63.5[48.5 ; 75.5]$ & $50.9[39.0 ; 63.0]^{*}$ \\
\hline
\end{tabular}

Also in the rats of the experimental group the 6-fold inhibition of redox processes compared to the control group $(\mathrm{P}<0.05)$ was observed. In the test to study the redox reactions of spermatozoa the restoration (discoloration) of methylene blue under anaerobic conditions due to the activity of respiratory enzymes was observed. The data obtained during the experiment indicate a mitochondrial respiratory impairment, the development of energy deficiency and, possibly, a decrease in the rate of basic biochemical processes that ensure the normal functioning of spermatozoa.
Conclusions. 1. The per cut application of $10 \%$ minoxidil containing lotion to male rats caused a decrease in morphometric parameters of the generative organs, as well as a change in the functional parameters of spermatozoa time of motility and respiration rate.

2. Takin into consideration the uncontrolled and long-term use of $10 \%$ minoxidil containing lotions by men of reproductive age an in-depth study of its gonadotoxic effects in experimental conditions in combination with epidemiological studies among patients using these lotions is deemed necessary.

\section{REFERENCES}

1. Rahban R, Priskorn L, Senn A et al. Semen quality of young men in Switzerland: a nationwide cross-sectional population-based study. Andrology, 2019; 7(6): 818-26. doi:10.1111/andr.12645

2. Agarwal A, Mulgund A, Hamada A, Chyatte MR. A unique view on male infertility around the globe. Reproductive biology and endocrinology. 2015; 13(1): 37-46.URL https://doi.org/10.1186/s12958-015-0032-1.

3. Semet M, Paci M, Saïas-Magnan J et al. The impact of drugs on male fertility: a review. Andrology. 2017; 5(4): 640-63. doi:10.1111/andr.12366

4. Brezina PR, YunusFN, Zhao Y. Effects of pharmaceutical medications on male fertility. Journal of reproduction \& infertility. 2012; 13(1): 3-11.

5. Milam EC, Rieder EA. An Approach to Cosmeceuticals. J Drugs Dermatol. 2016; 15(4): 452-6.

6. Trüeb R. The Difficult Hair Loss Patient. Guide to Successful Management of Alopecia and Related Conditions. Switzerland: Springer International Publishing. 2015; 317.
7. J. Stoehr J, Choi M, Colavincenzo S, Vanderweil Stefan. Off-Label Use of Topical Minoxidil in Alopecia: A Review. Am J Clin Dermatol. 2019; 20: 237-50.

8. Ho CH, Zito PM. Androgenetic alopecia.Treasure Island. Stat Pearls Publishing. 2019;

URL:https://www.ncbi.nlm.nih.gov/books/NBK430924

9. Freire P, Riera R, Martimbianco A et al. Minoxidil for patchy alopecia areata: systematic review and meta-analysis. J Eur Acad Dermatol Venereol. 2019; 33: 1792-99.

10. Randall VA. Androgens and hair growth. Dermatol Ther. 2008; 21: 314-28.

11. Toshihiro S, Taketsugu T, Tadashige $\mathrm{S}$ et al. Minoxidil increases $17 \beta$-hydroxysteroid dehydrogenase and $5 \alpha$ reductase activity of cultured human dermal papilla cells from balding scalp. Dermatological Science. 1999; 19: $123-5$.

12. Ceruti J, Leirós G, Balañá M. Androgens and androgen receptor action in skin and hair follicles. Molecular and Cellular Endocrinology. 2018; 465: 122-33.

13. Alzo'ubi M. Topical minoxidil 5\% induced male sexual 
dysfunction. Indian Journal of Medical Research and Pharmaceutical Sciences. 2017; 5: 23-7.

14. European convention for the protection of vertebrate animals used for experimental and other scientific purposes. Council of Europe, Strasbourg. 1986. 53 p.

15. Ruzen-Range E. Spermatogenez u zhivotnykh. [Spermatogenesis in animals]. M: Mir; 1980. $272 \mathrm{p}$.

16. Koptyaeva KY, Muzhikyan AA, GushchinYaA i dr. Metodika vskrytiya i izvlecheniya organov laboratornykh zhivotnykh (krysy). Technique Of Dissection And Extracting Organs of Laboratory Animals (Rats). Laboratory Animals for Science. 2: 71-92.

17. Metodicheskiye ukazaniya 1741-77: Metody eksperimental'nogo issledovaniya po ustanovleniyu porogov deystviya promyshlennykh yadov na generativnuyu funktsiyu $\mathrm{s}$ tsel'yu gigiyenicheskogo normirovaniya [1741-77 Methods of experimental research to establish thresholds for the effects of industrial poisons on the generative function for the purpose of hygienic regulation] (approved MH USSR 10.07.77). M: $1977.20 \mathrm{p}$.

18. Glantz SA. Primer of Biostatistics. 3-d ed., McGraw-Hill, Inc.-NY-Toronto. 1992. 440.

19. Abrashova TV, GushchinYaA, Kovaleva MA i dr. SPRAVOCHNIK. Fiziologicheskie, biokhimicheskie I biometricheskie pokazateli norm y eksperimentalnykh zhivotnykh. [Physiological, biochemical and biometric indicators of the norm of experimental animals]. SPB: «LEMA», 2013. $116 \mathrm{p}$.

20. Costello S, Michelangeli F, Nash $\mathrm{K}$ et al. Ca2+stores in sperm: their identities and functions. Reproduction. 2009; Vl(138): 425-37.

\section{ТОПІЧНИЙ ВПЛИВ ЛОСЬЙОНУ ІЗ ВМІСТОМ МІНОКСИДИЛУ НА МОРФОФУНКЦІОНАЛЬНІ ПОКАЗНИКИ РЕПРОДУКТИВНОЇ СИСТЕМИ ЩУРІВ-САМЦІВ}

В.А. Туркіна, Н.С. Чемодурова, О.І. Грушка, Г.В. Призиглей

Львівський національний медичний університет імені Данила Галицького, м. Львів, Україна

PЕЗЮМЕ. Вступ. Значної уваги в усьому світі викликає проблема алопеції, для лікування якої рекомендовано використання безрецептурних засобів - лосьйонів із вмістом міноксидилу. Їх споживачі через певні психологічні застереження рідко звертаються до медиків. Отжке, це сприяє безконтрольному використанню засобів, а фіксація їхніх побічних ефектів стає неможливою. Улітературі з'являються поодинокі повідомлення щодо впливу лосьйонів із вмістом міноксидилу на фертильність у чоловіків.

Мета. Встановити органометричні показники сім'яників та їхніх придатків і функціональні параметри сперматозоїдів у статевозрілих шурів при топічному впливові лосьйону із вмістом $10 \%$ міноксидилу.

Методи. Аналітичні, токсикологічні, статистичні.

Результати. Встановлено, що в умовах 72-денного перкутанного нанесення лосьйону із вмістом $10 \%$ міноксидилу відбуваються зміни в органах репродуктивної системи, які проявляються зниженням маси сім'яників і епідидимусів, а також зміною лінійних розмірів органів у бік зменшення. Загальний час рухової активності статевих клітин після впливу лосьйону із вмістом $10 \%$ міноксидилу має статистично достовірне зниження, також спостерігалась загальмованість активності окисно-відновних процесів у 6 разів у шурів експериментальної групи порівняно із контрольною.

Висновки. Враховуючи отримані дані та безконтрольне і довготривале застосування лосьйонів із вмістом $10 \%$ міноксидилу чоловіками репродуктивного віку, необхідне поглиблене вивчення його гонадотоксичних ефектів в експериментальних умовах у комплексі із епідеміологічними дослідженнями серед пацієнтів, що використовують дані лосьйони.

Ключові слова: міноксидил, гонадотоксичність, статевозрілі шури.

\section{ТОПИЧЕСКОЕ ВЛИЯНИЕ ЛОСЬОНА, СОДЕРЖАЩЕГО МИНОКСИДИЛ НА МОРФОФУНКЦИОНАЛЬНЫЕ ПОКАЗАТЕЛИ РЕПРОДУКТИВНОЙ СИСТЕМЫ КРЫС-САМЦОВ}

В.А. Туркина, Н.Е. Чемодурова, О.И. Грушка, А.В. Призиглей

Львовский национальный медицинский университет имени Данила Галицкого, г. Львов, Украина

РЕЗЮМЕ. Введение. Пристальное внимание во всем мире вызывает проблема алопеции, для лечения которой рекомендуется использование безрецептурных средств - лосьонов с содержанием миноксидила. Их потребители из-за определенных психологических предрассудков редко обращаются к медикам. Потому эти средства бесконтрольно используются, а фиксация их побочных эффектов становится невозможной. В литературе появляются единичные сообщения о влиянии лосьонов, содержащих миноксидил, на фертильность у мужчин.

Цель. Установить органометрические показатели семенников и их придатков, а также функциональные параметры сперматозоидов у половозрелых крыс при топическом воздействии лосьона, содержащего $10 \%$ миноксидила.

Методы. Аналитические, токсикологические, статистические.

Результаты. Установлено, что в условиях 72-дневного перкутанного нанесения лосьона с содержанием $10 \%$ миноксидила происходят изменения в органах репродуктивной системы, проявляющиеся снижением массы семенников и эпидидимусов, а также уменьшением линейных размеров органов. Общее время двигательной активности половых клеток после воздействия указанного лосьона статистически достоверно снижено, также замедлялась активность окислительно-восстановительных процессов в 6 раз у крыс экспериментальной группы по сравнению с контрольной.

Выводы. Учитывая полученные данные, бесконтрольное и длительное применение лосьонов с содержанием $10 \%$ миноксидила мужчинами репродуктивного возраста необходимо углубленное изучение его гонадотоксических эффектов в экспериментальных условиях в комплексе с эпидемиологическими исследованиями среди пациентов, использующих данные лосьоны. Ключевые слова: миноксидил, гонадотоксичность, половозрелые крысы. 